تأثير قدرت جريان ثانويه بر تنش برشى بستر ييرامون آبشكن سرسيرى مستقر در موقعيتهاى مختلف قوس 9 در جحه با بسترصلب

محمد واقفى '”، مسعود قدسيان’ و مريم اكبرى'

(تاريخ دريافت:

جִكيده

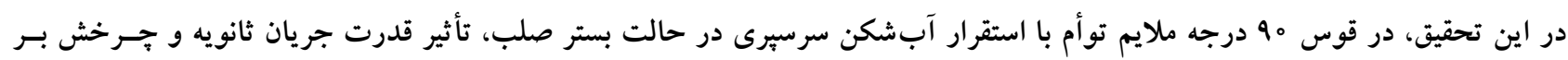

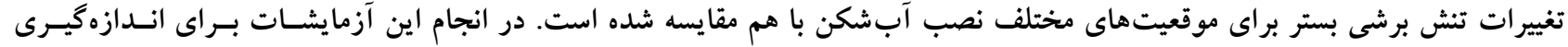

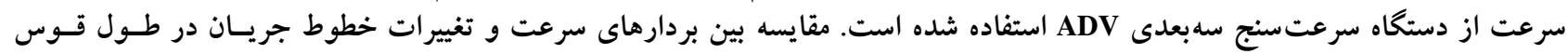

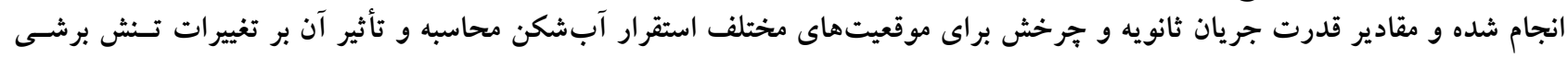

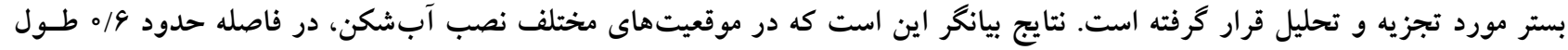

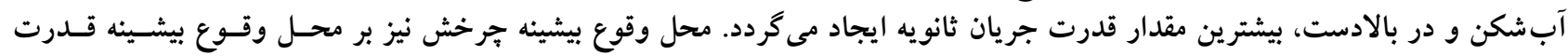

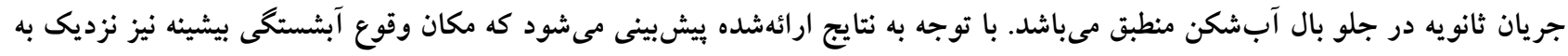

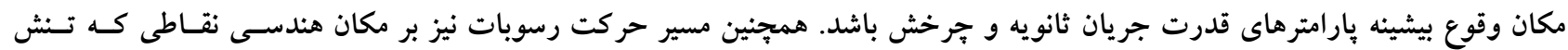
برشى بيشترى دارند، منطبق مى باشد.

وازگان كليدى: قدرت جريان ثانويه، تنش برشى بستر، آبشكن سرسبرى، سرعتسنج سهبعى

1. كروه مهندسى عمر ان، دانشكده فنى و مهندسى، دانشكاه خليج فارس

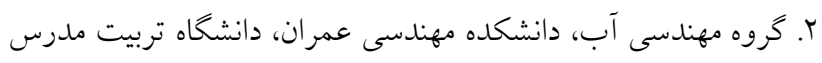

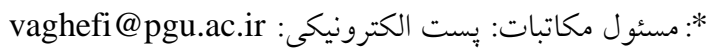


دو بعدى متوسط گيرى شده در عمق، الكوى جريان در دو قوس

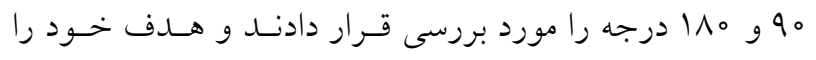

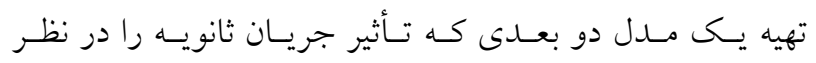

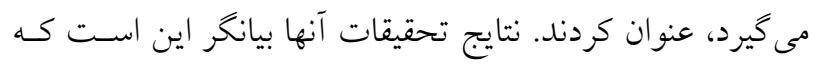

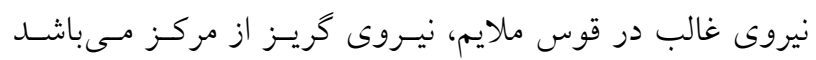

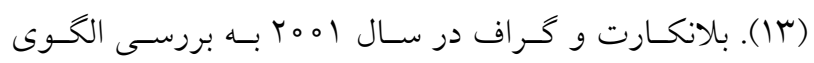

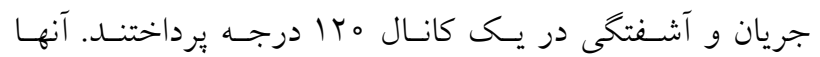

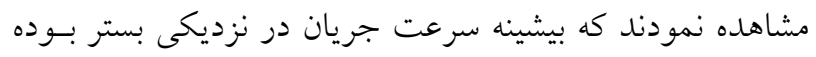
و يك جريان جرخشى مركزى نيـز در ايسن مقطع وجـود دارد.

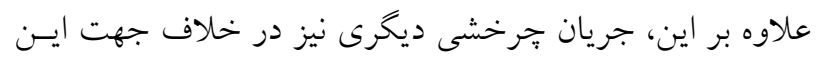
جريان در نزديكى قوس بيرونى وجود داشته و بيشسينه سـرعت نيز در مرز اين دو سـلول جرخشى اسـت (9). يانــ در سـال

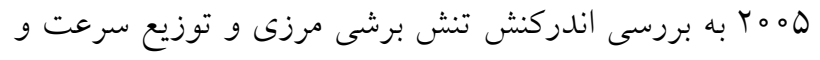

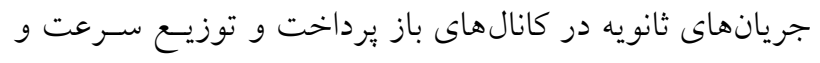

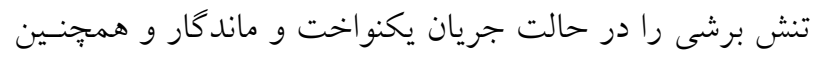

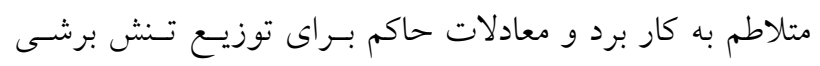

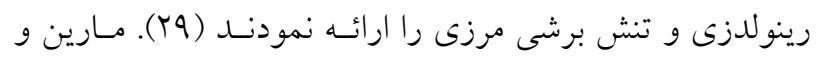

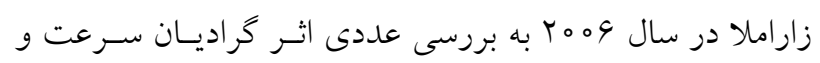

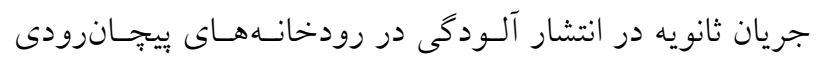

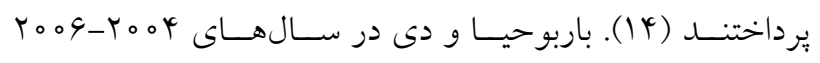

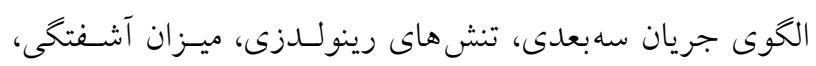

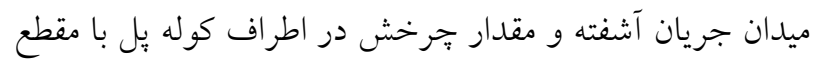

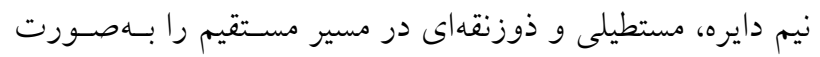

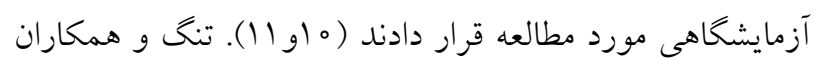

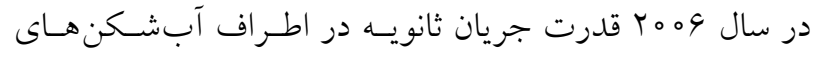

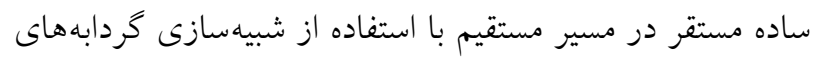

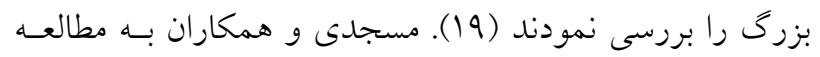

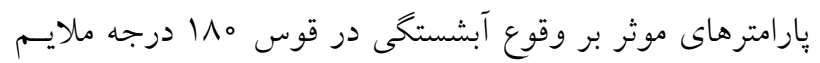

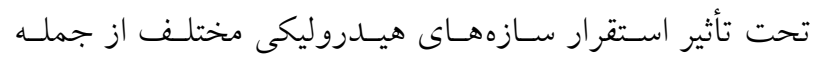

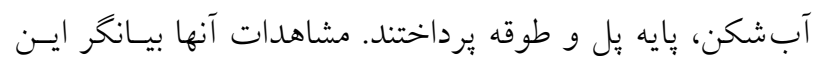

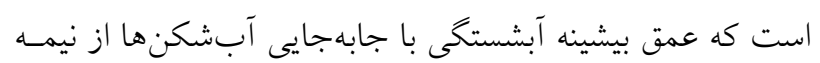

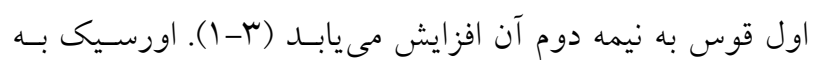

قسمت هاى خميده يكى رودخانه از جمله بـازههـاى بحرانسى در

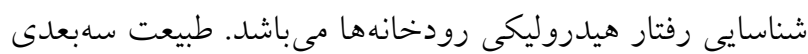

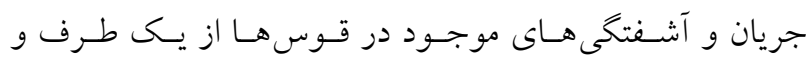

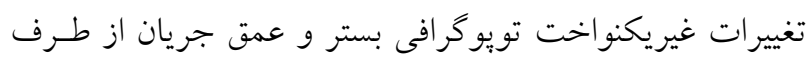
ديخر باعث تشكيل جريانهاى ناشناختهاى در قوس رودخانههـا

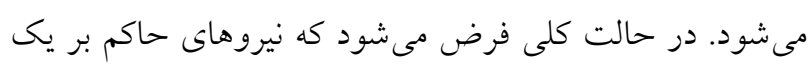

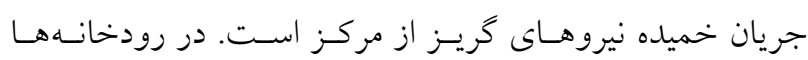

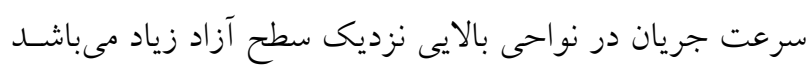

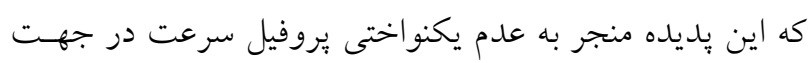

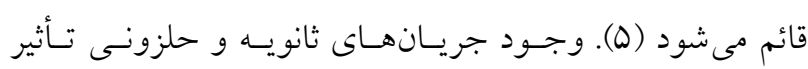

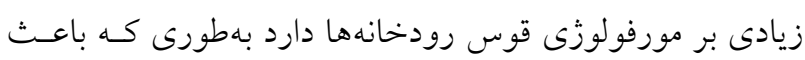
حمله شديد به بسـتر رودخانهه و سـاحل خـارجى و در نتيجـه

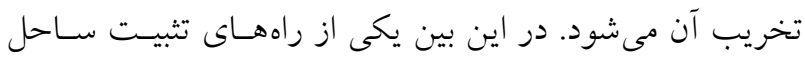

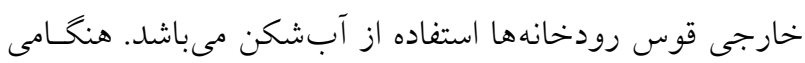

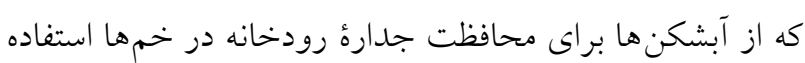

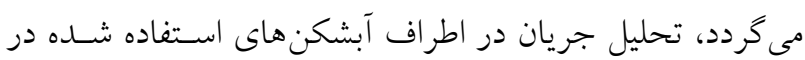

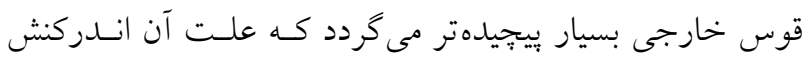

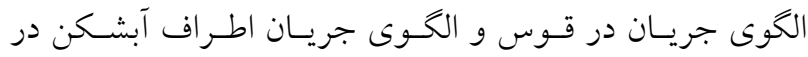
قوسها مىباشد (4).

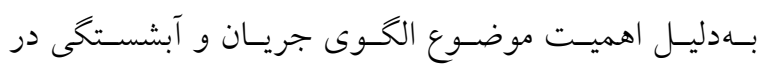

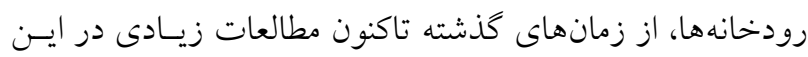

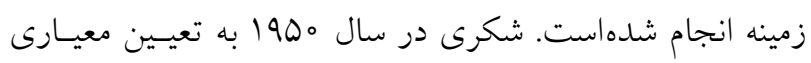

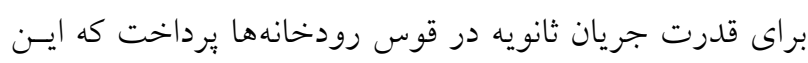
معيار در يك مقطع عرضى معين، نسبت انرزى جنبشى جرئ جريسان

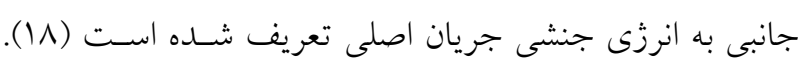

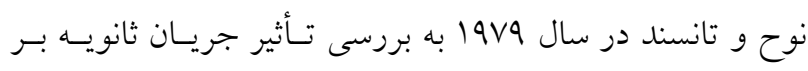

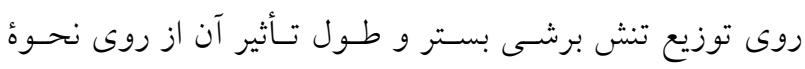

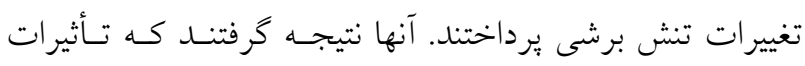

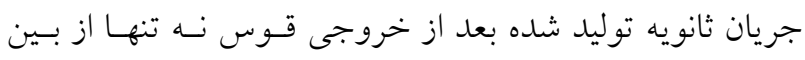

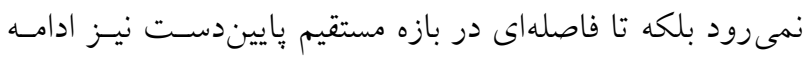

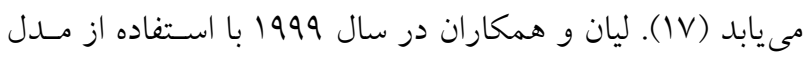




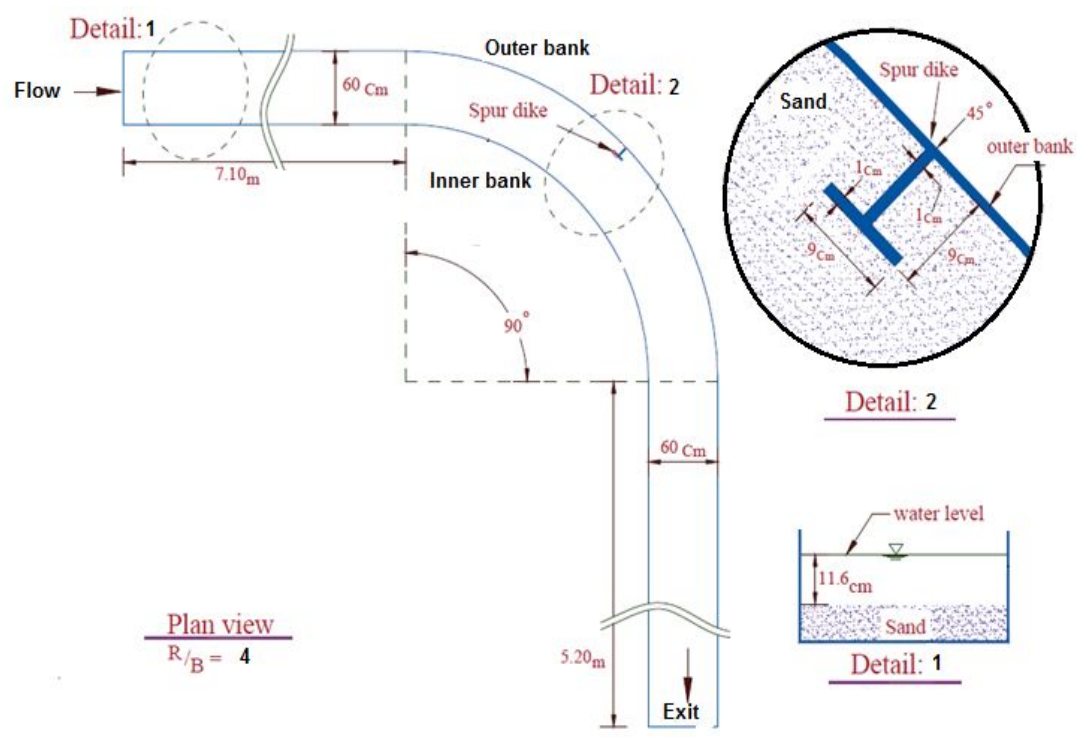

شكل 1. بِلان كانال آزمايشخاهى مورد نظر

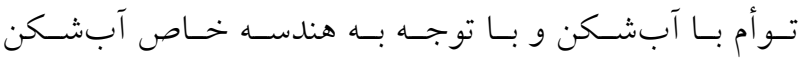

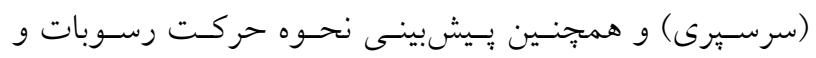

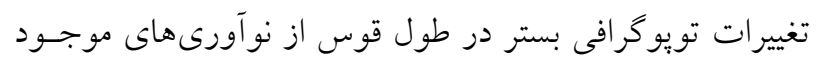
در اين مقاله مىباشد.

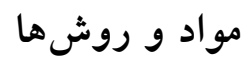

آزمايشات در كانالى با زاويه مركزى ه9 درجسه در آزمايشـاه

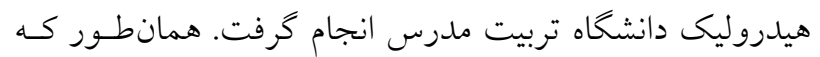
در شكل ا مشاهده مى شود، اين كانال از يك قسـمت مستستقيم

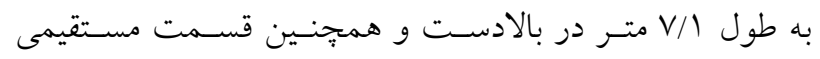
بلهول ه/T متر در ياييندست تشكيل شده كه ايـن دو قسـمت

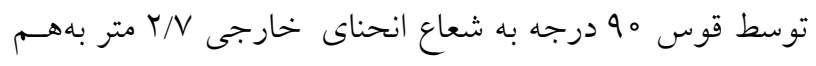

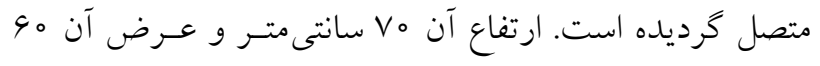

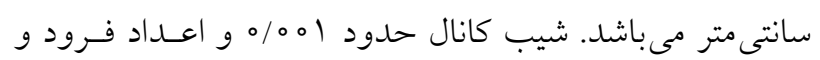

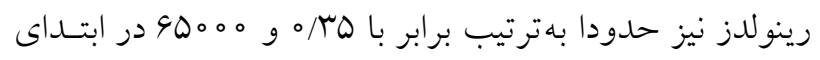

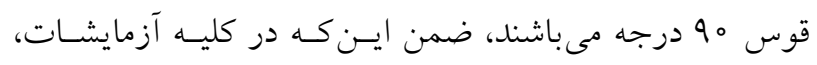

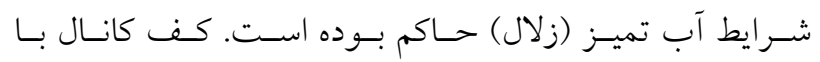

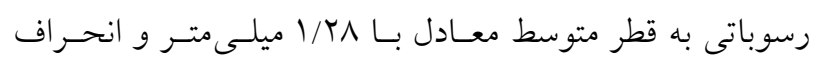

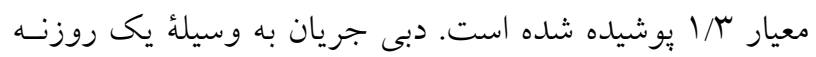

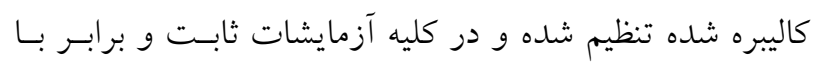

بررسى آزمايشگاهى روش هاى مختلف براى محاسـبه تـنش

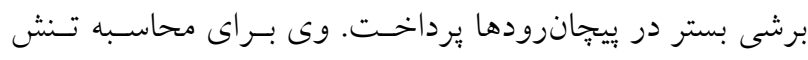

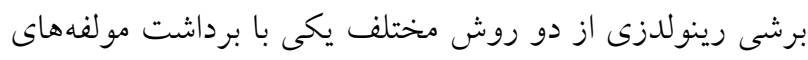

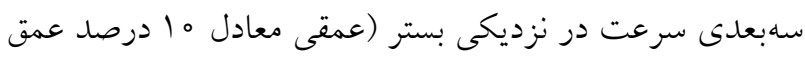

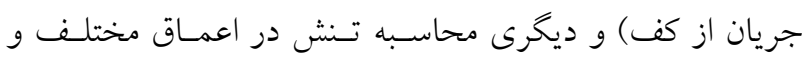

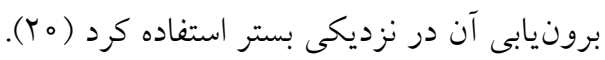

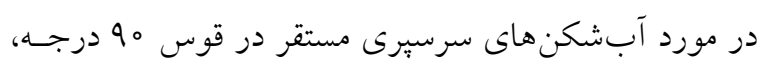

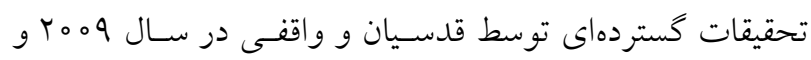

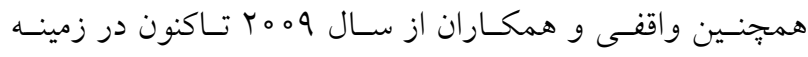

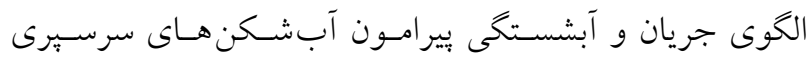

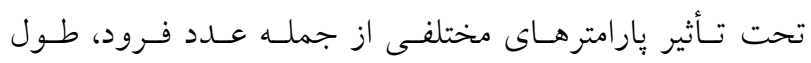

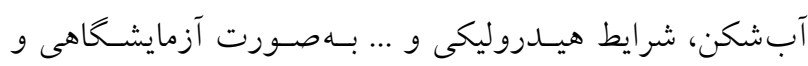

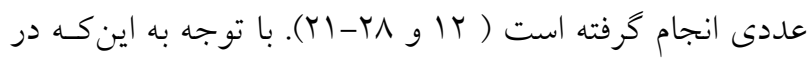

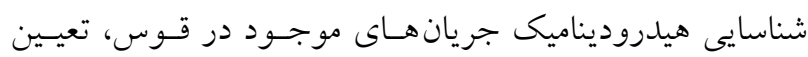

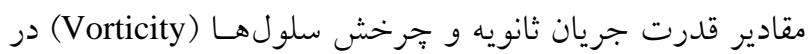
مقاطع عرضى مختلف در اطر اف سـازهــاى هيـدروليكى نظيـر آبشكن مى تواند نقش تعيين كنندهاى داشته باشد، در اين مقاله

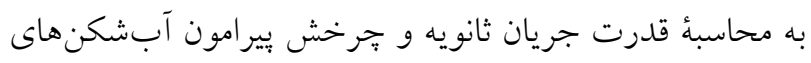

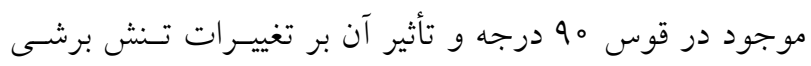

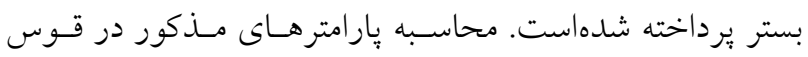


Explore V و Vecterino

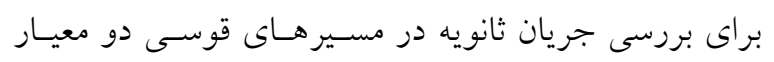

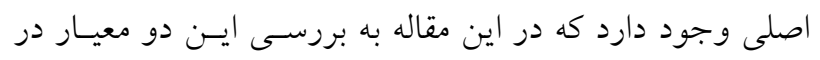

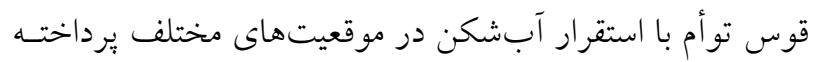

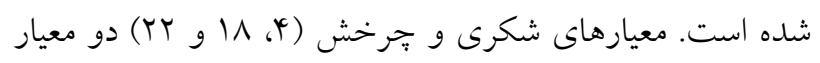
مهم در محاسبه كمى جريانهاى ثانويه مى باشند كه با در دست

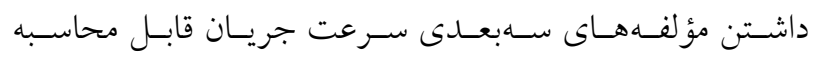

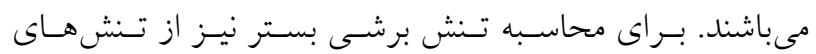

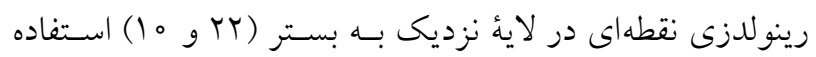

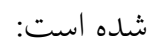

$\tau_{\mathrm{b}}=\left(\tau_{\mathrm{x}}{ }^{r}+\tau_{\mathrm{y}}{ }^{r}\right)^{\circ / \Delta}$

$\tau_{\mathrm{x}}=\rho\left(\overline{\mathrm{w}_{\mathrm{i}}{ }^{\prime} \mathrm{u}_{\mathrm{i}}{ }^{\prime}}+\overline{\mathrm{v}_{\mathrm{i}}{ }^{\prime} \mathrm{u}_{\mathrm{i}}{ }^{\prime}}\right)$

$\tau_{\mathrm{y}}=\rho\left(\overline{\mathrm{v}_{\mathrm{i}}{ }^{\prime} \mathrm{u}_{\mathrm{i}}{ }^{\prime}}+\overline{\mathrm{v}_{\mathrm{i}}{ }^{\prime} \mathrm{w}_{\mathrm{i}}{ }^{\prime}}\right)$

$u_{i}{ }^{\prime}=u_{i}-\bar{u}$$$
\mathrm{v}_{\mathrm{i}}{ }^{\prime}=\mathrm{v}_{\mathrm{i}}-\overline{\mathrm{v}}
$$$$
\mathrm{w}_{\mathrm{i}}{ }^{\prime}=\mathrm{w}_{\mathrm{i}}-\overline{\mathrm{w}}
$$

در روابط بالا،

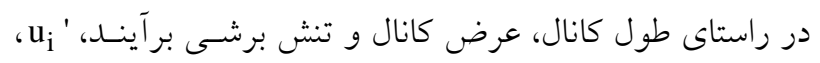

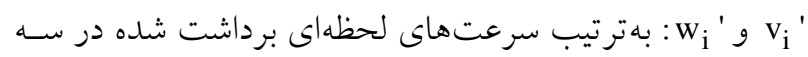
راستاى طـول، عـرض و ارتفـاع كانـال،

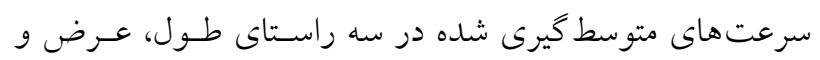

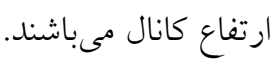

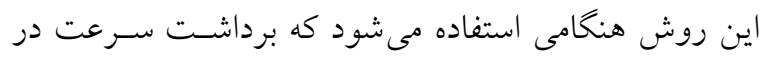

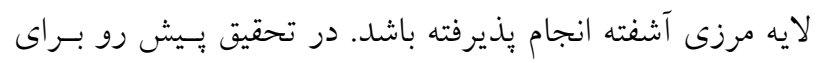

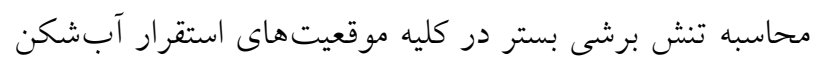

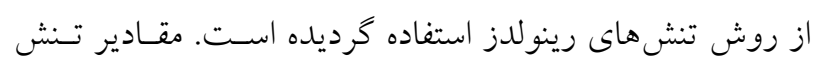

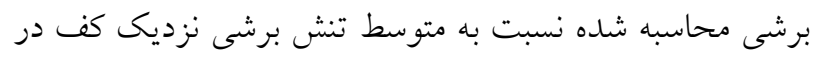

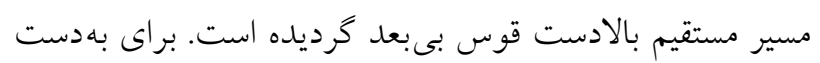

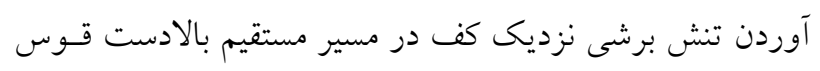

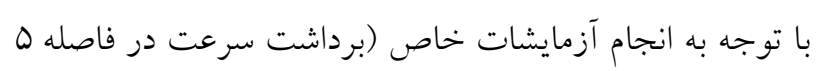

قو ليتر بر ثانيه مىباشد. براى كنترل جريان نيز از يـك دريجهـ

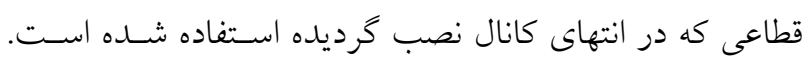

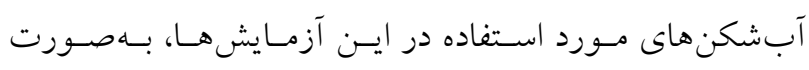

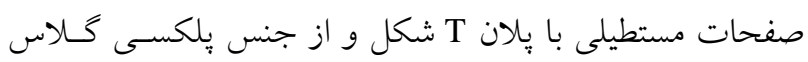

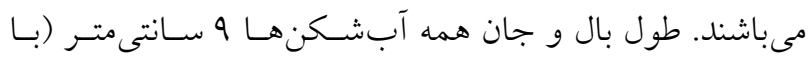

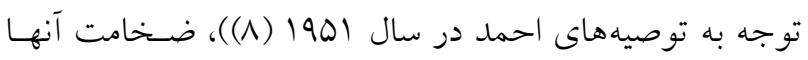

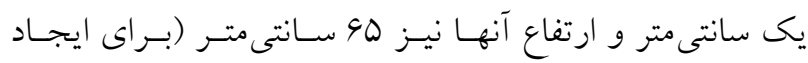

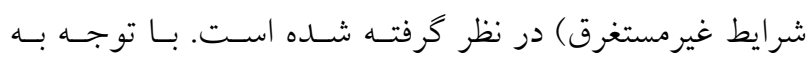

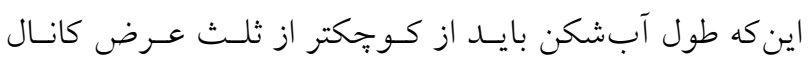

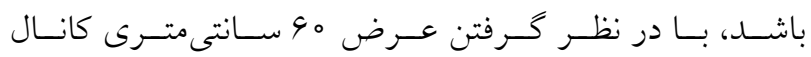

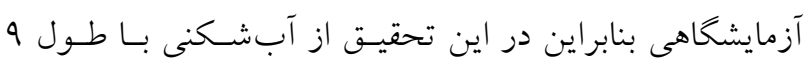

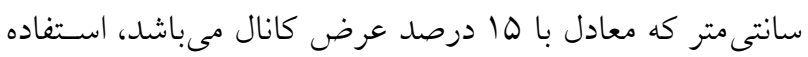

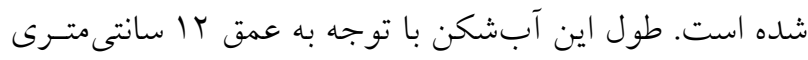
جريان و بنا به توصيههـاى ملويـل (10) و و ياسسى و همكــاران

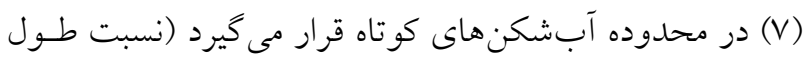
آب شكن به عمق جريان كمتر از (1).

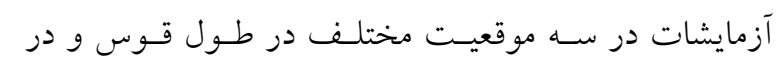

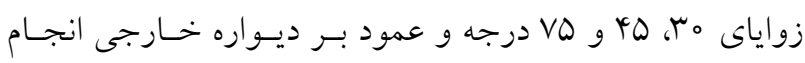

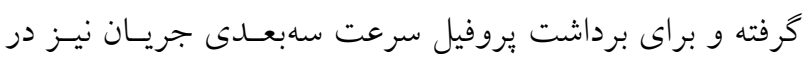

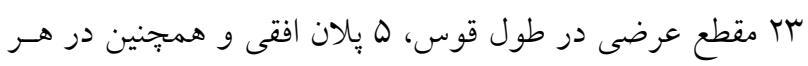

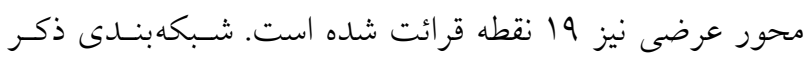

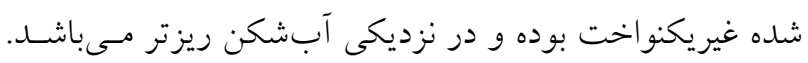

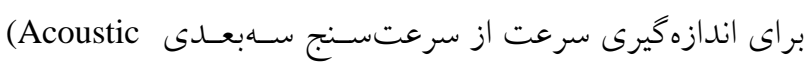
ADV Doppler Velocimeter)

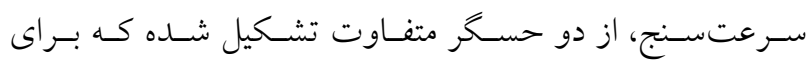

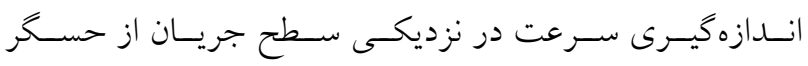

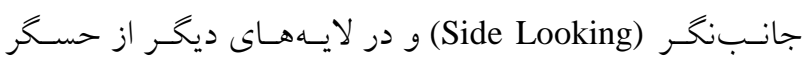

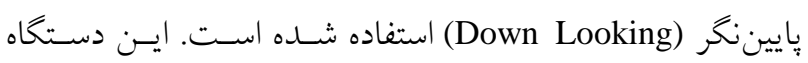
براى فركانس •ه هرتز تنظيم شده و مدت زمان اندازه كيرى هر نقطه از شبكهبندى تعريف شده نيز 9 ثانيه بوده است، بنابراين

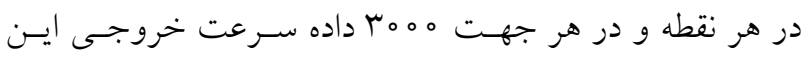

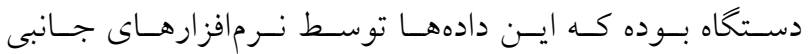




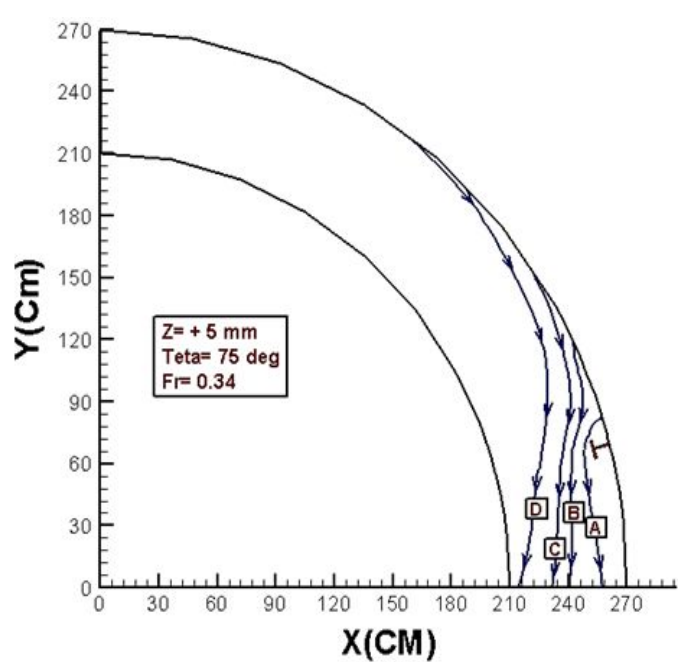

(4)

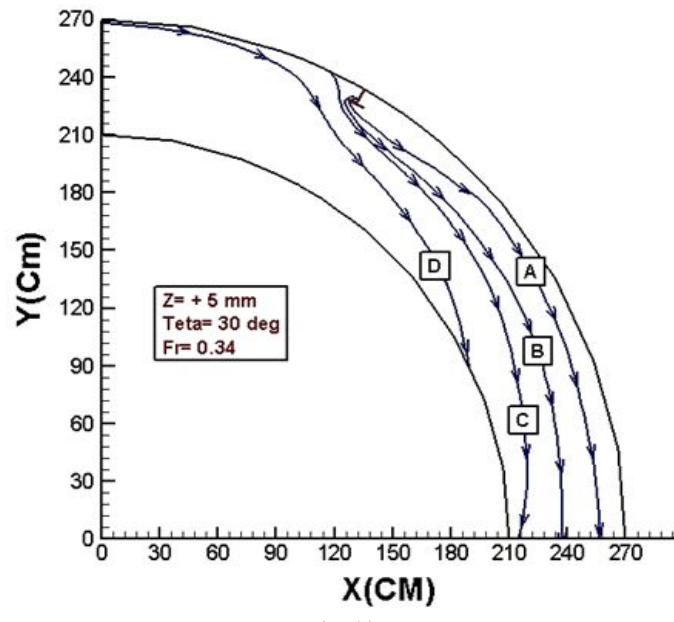

(الف)

شكل r. نمونهاى از خطوط جريان در تراز نزديك به بستر در موقعيت استقرار آبشكن

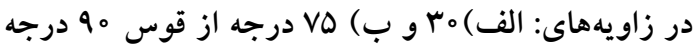

افق براى آبشكن مستقر در نيمه ابتدايى قوس (شكل r-الـف)

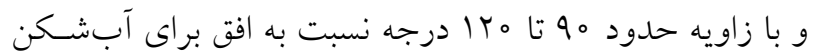

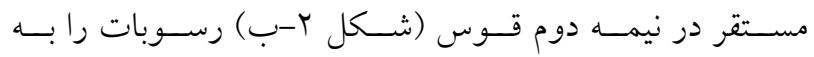

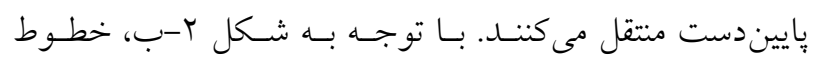

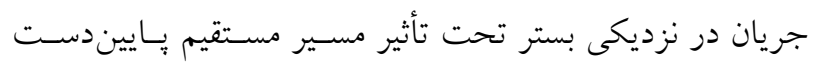

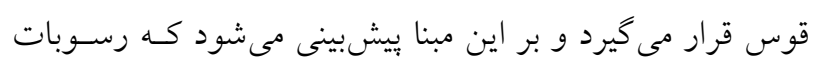

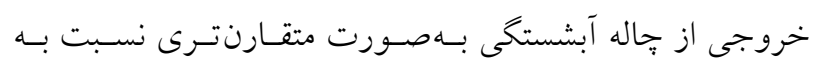

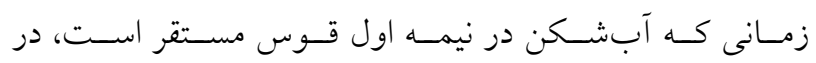

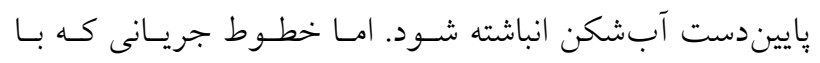
حرف D نشان داده شده است، در واقع مسير ديكرى از حركت إنت

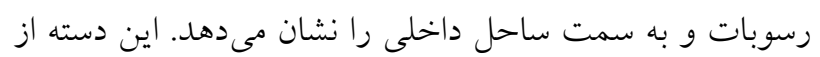

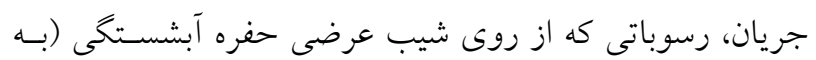

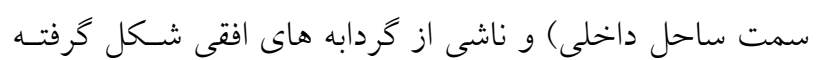

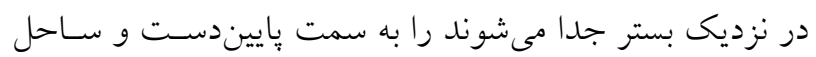

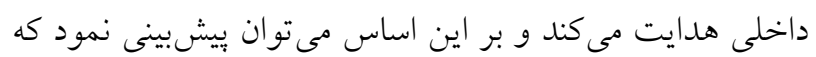
بيشترين ميزان رسوبكذارى در نزديكى ساحل داخلى مىباشد.

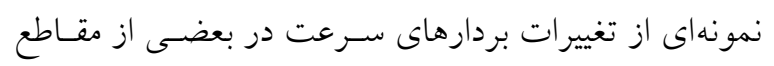
اندازهيرى شده و مكان هندسى خط سرعت بيشينه جريـان در

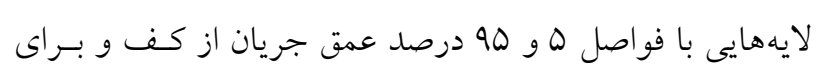

درصدى عمق جريان از كـف) در مسـير مستقيم بالادست، از همان روش تنشهاى رينولدزى استفاده كرديده است.

\section{نتايج و بحث}

در شكل ץ نمونهاى از خطوط جريان در تراز نزديـى بـه بسـتر (ه درصــ عمـق جريـان از كـف) بـــاى دو موقعيـت اسـتقرار آبشكن در زاويههاى مبا و VD درجه نشـان داده شــده اسـت. همانطور كه مشاهده مىشود خطوط جريان در نزديكى بستر به ץ أ دسته كلى تقسيم مى گردد. در گروه A خطوط جريان نزديـى

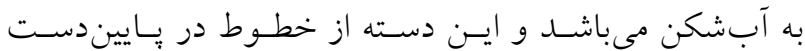

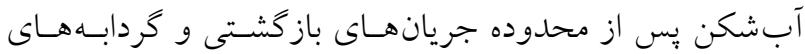
پايين دست به ساحل خارجى نزديك مى شوند و بههمسين دليـل

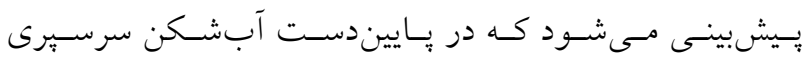

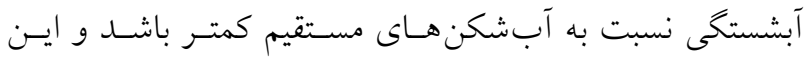

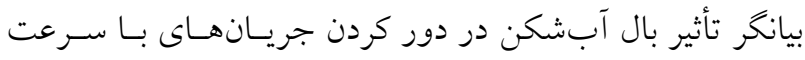

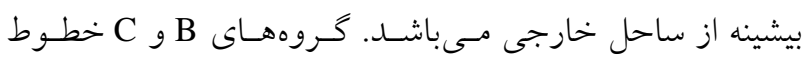

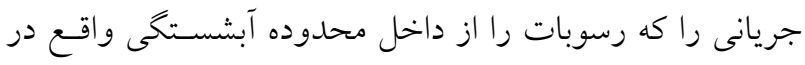

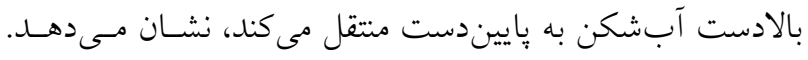

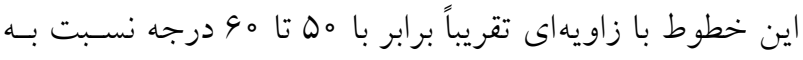




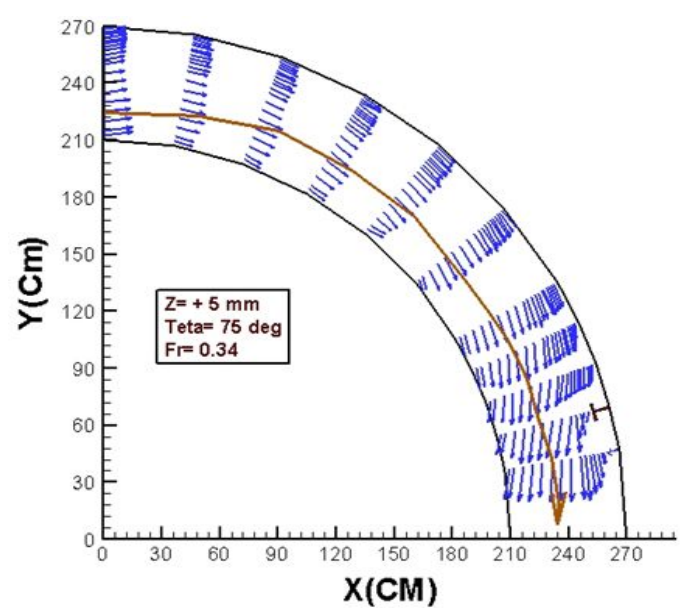

(ب)

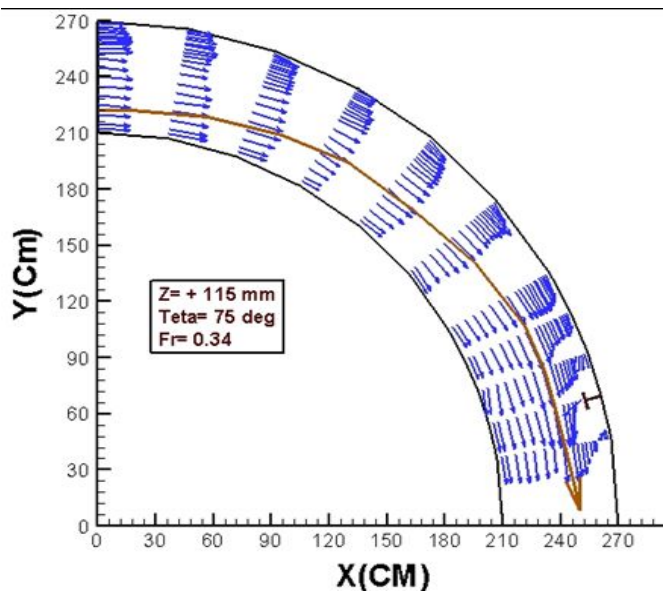

(د)

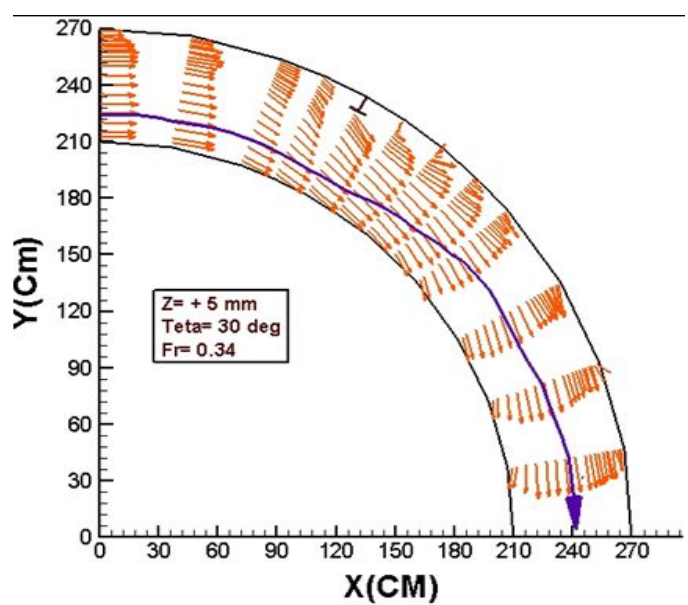

(الف)

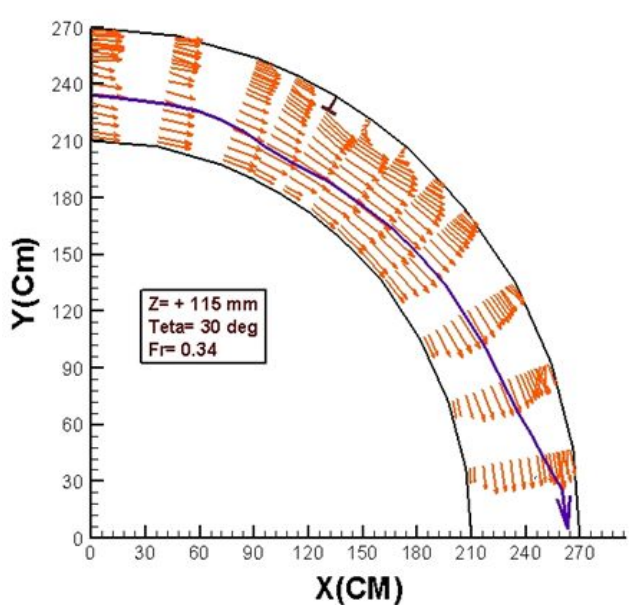

(ج)

شكل r. نمونهاى از تغييرات بردارهاى سرعت و مكان هندسى خط سرعت بيشينه جريان در: الف) و ج) ترازهايى به فواصل: ه و هو هو درصد عمق جريان از كف براى آبشكن مستقر در موقعيت •r درجه

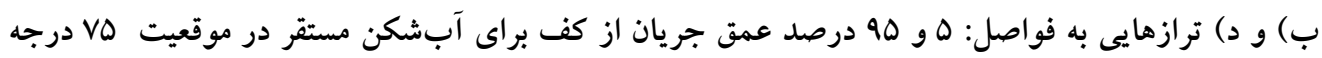

كف و نزديك بـه سـطح آزاد بـهـــورت هــمزمـان در حالـت

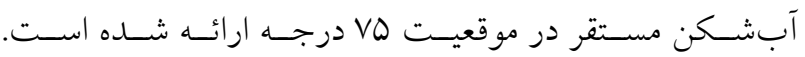
اندازه كيرى متوسط زاويه خطوط جريان بيـانخر ايسن اسـت كـه اختلاف زاويه بين خطوط جريان در لايه نزديك بستر و نزديك سطح آزاد در بالادست محل استقرار آبشكن حدود با درجـه

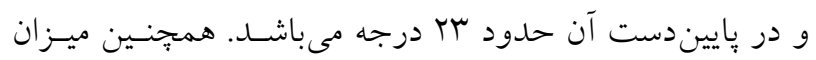
متوسط اختلاف زاويه ذكر شده نيز V/D درجه مىباشد. مقـادير ذكر شده بيانگر تأثير آبشكن سرسـيرى در انحـراف خطـوط جريان بهخصوص در لايه نزديك به بستر و در نتيجه ييشبينى

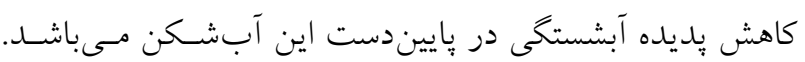

آبشكنهاى مستقر در موقعيتهاى هب و VQ درجه در شكل r

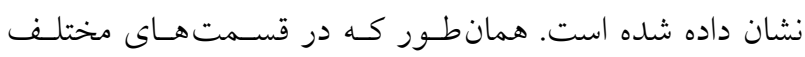
شكل ب مشاهده مىشود، در محسدوده اطـراف آبشـــن مسـير

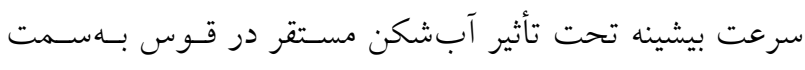
ساحل داخلى منحرف شده است. مقايسه شكل هـاى (r- الـف)

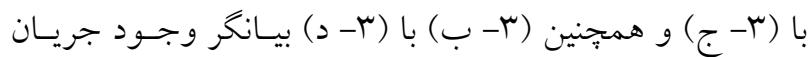
ثانويه بهدليل تغيير مكان هندسى خـط سـرعت بيشـينه از لايـه نزديك به كف تا لايه نزديك به سطح، بهسمت ساحل خـارجى مىباشد. در شكل با نمونهاى از خطوط جريـان در لايسه نزديـك بـه 

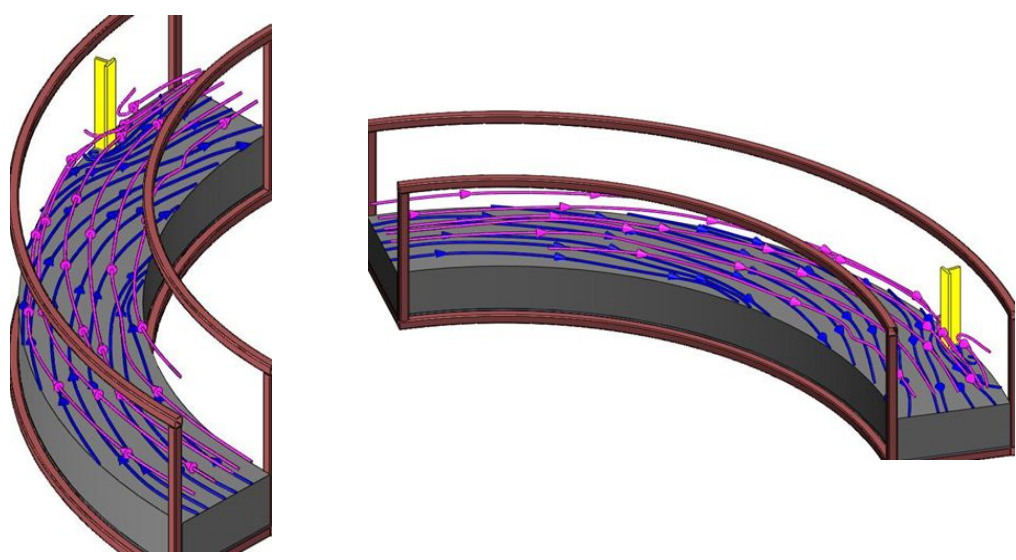

شكل †. نمونهاى از خطوط جريان در لايه نزديك به كف و سطح آزاد بهصورت همزمان در

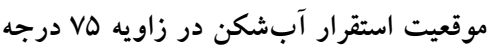

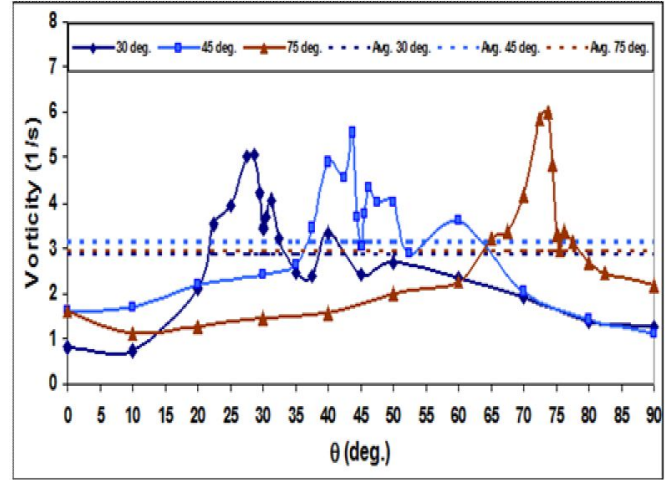

(ب)

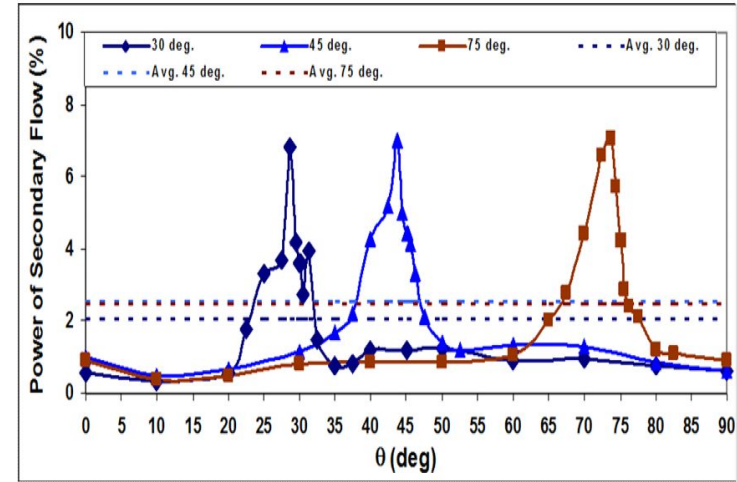

(الف)

شكل ه. معيارهاى محاسبه جريان ثانويه براى آبشكن مستقر در موقعيتهاى مختلف در طول قوس

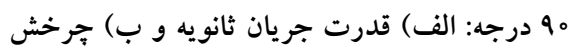

باتوجابه شكل ه، در فاصله حدود 9/ه طول آبشكن و در

بالادست بيشترين مقدار قدرت جريان ثانويه مشاهده مى گـردد. همجينين از فاصله حدود 9/ه طول آبشكن تا جـان آبشـن كه محدوده بين ديواره بال بالادست و ساحل خارجى مىباشـد، اين روند بهدليل ايجاد محدوده كم سـرعت و افـزايش سـرعت طولى در بقيه مقطع، نزولى مىشود. اين روند نزولى تا فاصلهاى حدود V تا ^ برابر طول آبشكن و در ياييندست ادامه داشته و از آنجا تا انتهاى قوس از روند تقريباً يكنواختى برخوردار است. علت افزايش قدرت جريان ثانويسه از بالادسـت تـا دماغـه بـال آبشكن، تنخ شدگى مقطع و افزايش مولفه سرعت عرضسى و تمايل به ايجاد ناحيه جداشدگى جريان مسىباشـد. در محسدوده
معيارهاى ذكر شـده در جهـت تعيسين كمسى جريـان ثانويـه (قدرت جريان ثانويه و جرخش) موجود در طـول قـوس بـراى

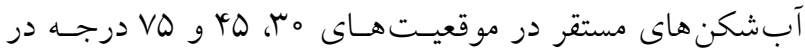
شكل ها ارائه گرديده است. در اين شكل مقادير متوسط قـدرت جريان ثانويه و جرخش در هر مقطع به همـراه مقـادير متوسط هر يك از اين مقادير در طول قوس ارائه شده است. با توجه به شكل (ه- الف) مشاهده مىشود كه در هر سه حالت، تا حسدود ه/Dه تا 9/0برابر طول آبشـكن و در بالادسـت مقـادير قـدرت جريان ثانويه از نرخ تقريبـاً يكنـواختى برخــوردار بــوده و از آن فاصله تا حدود 9/ه طول آبشكن و در بالادست ايسن رونـد از نرخ صعودى برخوردار مىباشد. 
محدوده تغير ات صعودى و نزولى منحنى ها تقريباً با قـدرت

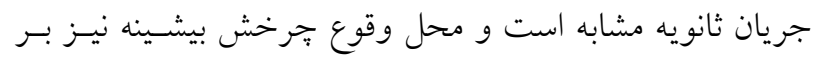

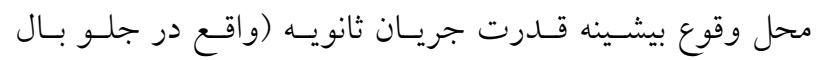

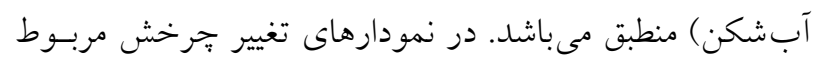

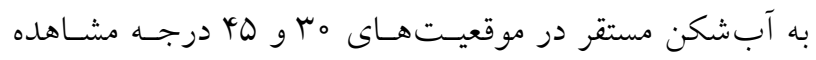

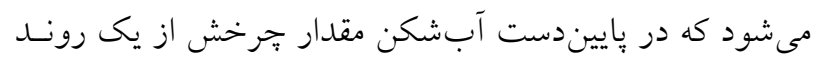
نزولى - صعودى برخهوردار اسـت كـه قسـمت نزولسى نمـودار

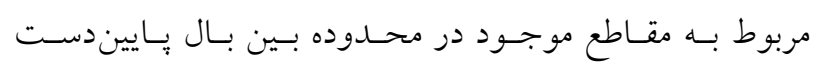

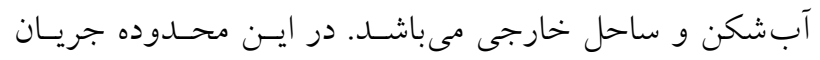

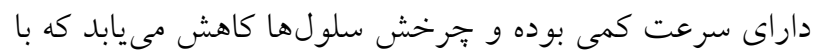

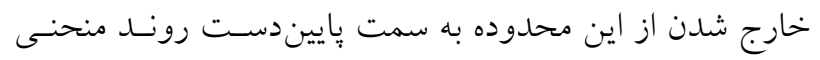

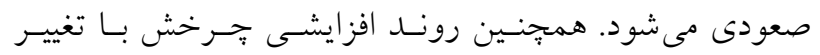

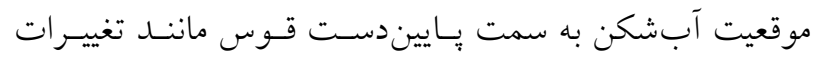

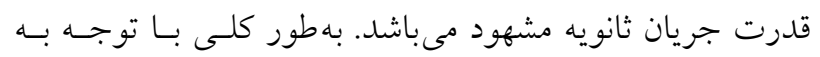

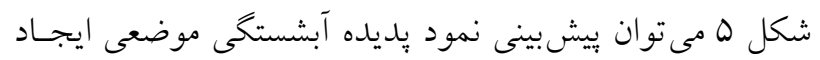

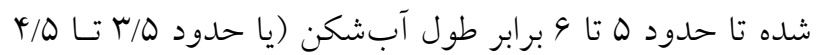

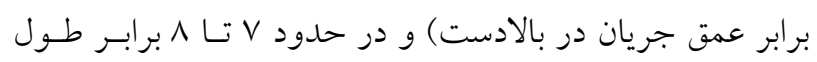

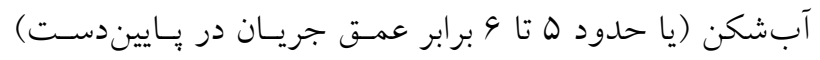

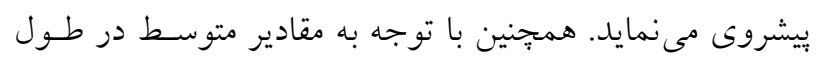

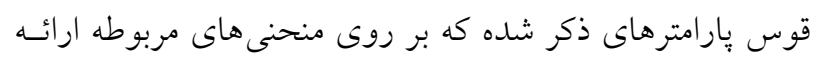

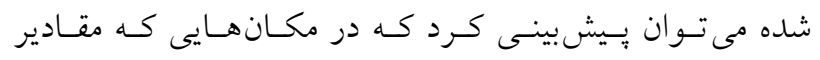

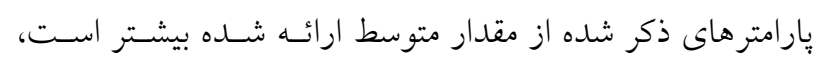

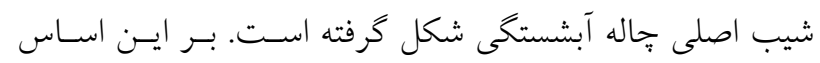

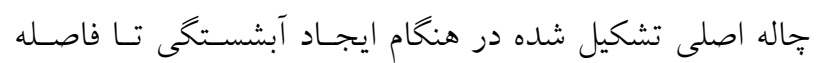

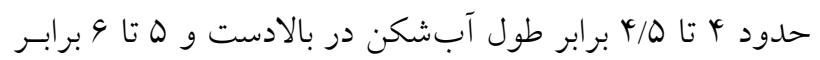

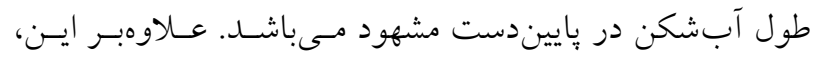

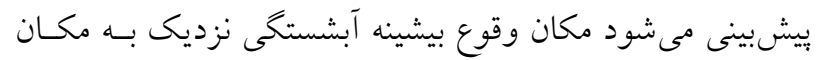

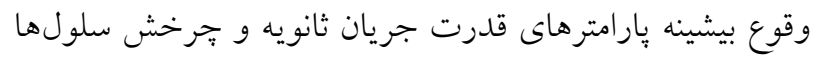

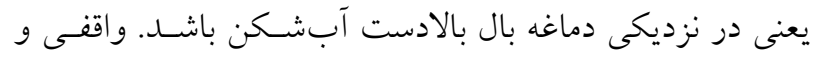
همكاران (Tr) مقادير قدرت جريان ثانويه، جرخش سلولهــا و و

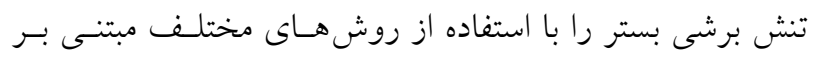

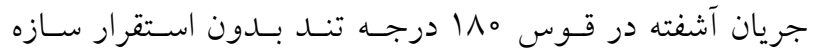

بين بال بالادست آبشكن و ساحل خـارجى بـهدليـل برخـورد

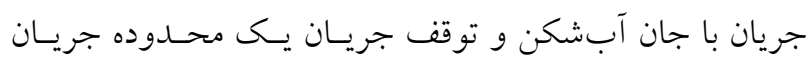

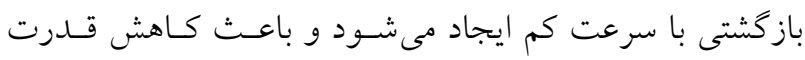

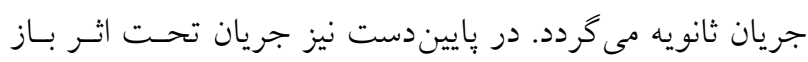

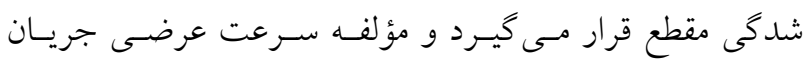

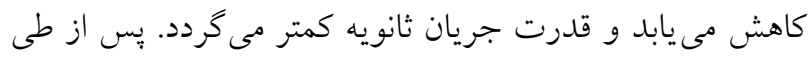

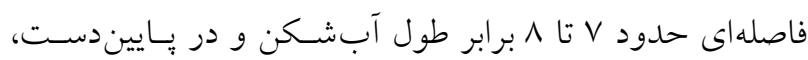

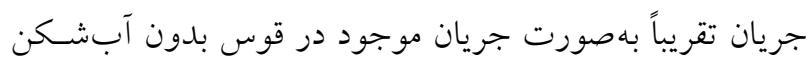

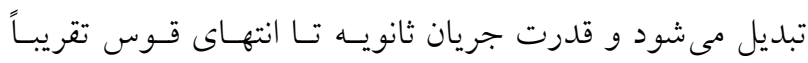
يكنواخت مىشود. بهطور كلى مى تـوان نتيجهـ كيــى نمـود كـهـ شكل (ه- الف) بيانكر اين است كه با تغييـر موقعيـت اسـتقرار آبشكن به سمت باييندست قوس مقادير قدرت جريان ثانويه

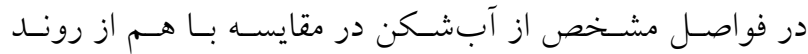

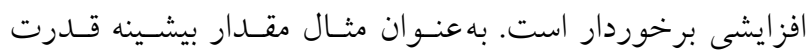

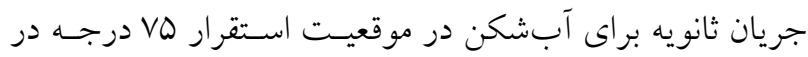

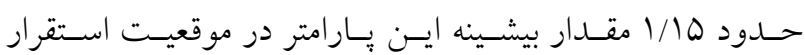
آبشكن در زاويه هب درجه مى باشد.

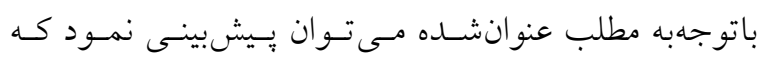

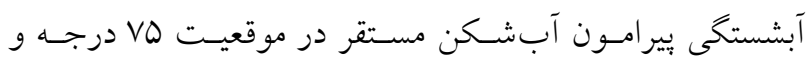

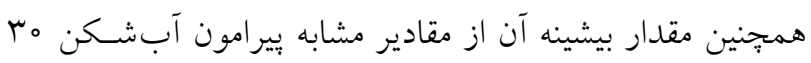

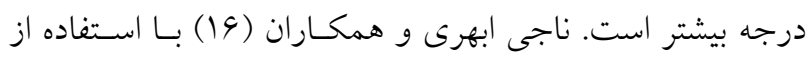

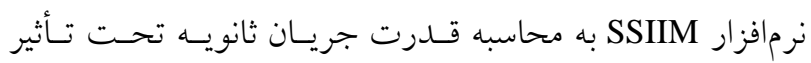

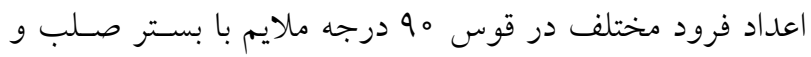

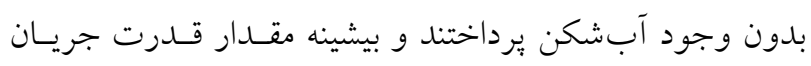

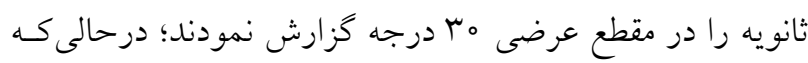

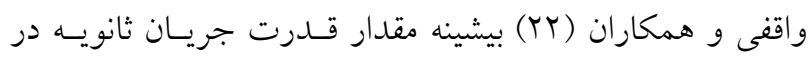

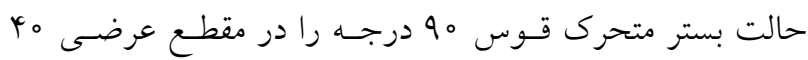

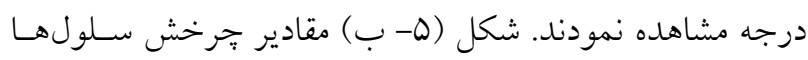

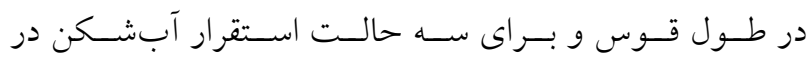

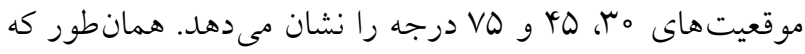

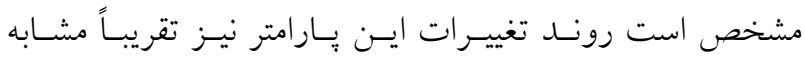
تغييرات قدرت جريان ثانويه در شكل (ه- الف) مىباشد. 


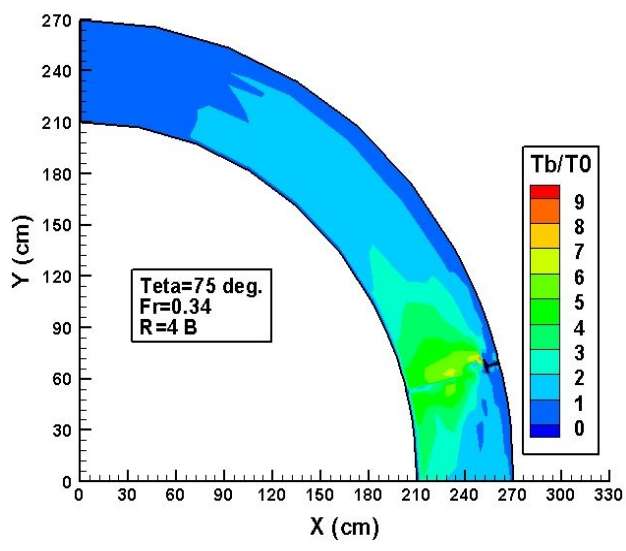

(ب)

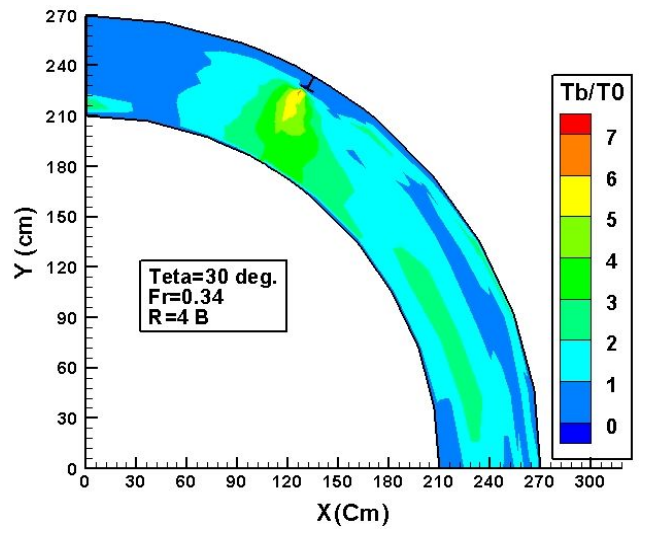

(الف)

شكل 9. كانتورهاى تنش برشى بىبعد شده بستر نسبت به تنش برشى متوسط بستر در مسير مستقيم بالادست با

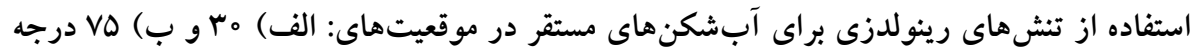

ساحل داخلى و با توجه به تنش برشى زيادى (تـا حسدود جنــ

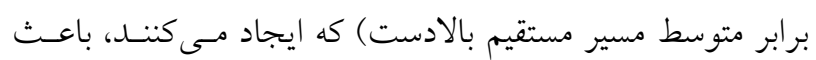
حركت يرتاب كونه رسوبات بـه سـمت يـايين دسـت در طـول آزمايش و به خصوص در شروع آزمايشات مى شود. با توجه بـه شكل 9 ملاحظه مى گردد كه در ساحل خارجى و در باييندست آبشكن، تنش برشى نسـبت بـه نقـاط ديخـر كمتـر بــوده كـه مى تواند عاملى در جهت كاهش آبشستخى در سـاحل خـارجى ياييندست باشد. همجنين بيش بينى مى شود كـه مسـير حركـت رسوبات بر مكان هندسى نقاطى كه تنش برشى بيشترى دارنـد، منطبق باشد. مقايسه شكل هاى (4- الف) و (4- ب) بيانگر افزايش مقدار تنش برشى با تغيير موقعيت آبشكن بـه سـمت يـاييندسـت قوس مىباشد و بر اين اساس مىتوان بيشبينى نمود كه با تغيير

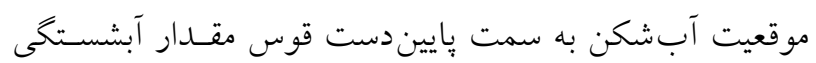
بيشتر مىشود. شكل V نمودار تنش برشى بى بعد شده نزديك بـه بسـتر در

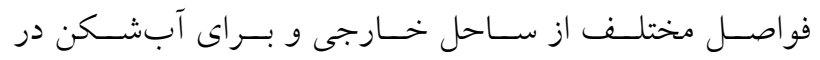
موقعيتهاى مبرو VD درجه را نشان مي مدهد.

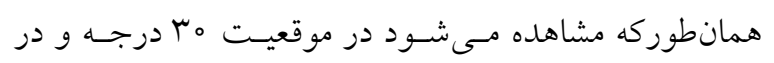
فاصله معادل ه درصد عرض كانال از ساحل خارجى (شكل V-

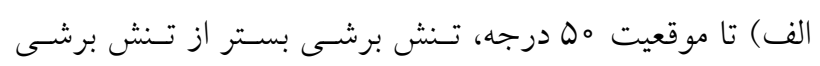

هيدروليكى را نيز بهصورت آزمايشخاهى مورد بررسى قرار داده

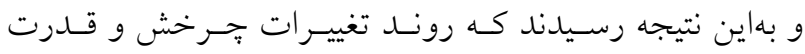

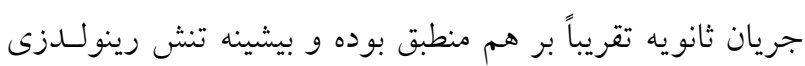
نيز در محدوده افزايش اين دو بارامتر مىباشد. كانتورهاى تنش برشى بـى بعـد شـده در نزديكسى بسـتر بــا

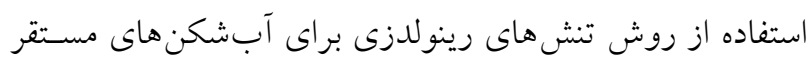
در موقعيتهــاى مل و VD درجـه در شـكل و نشـان داده شـده است. همانطور كه مشاهده مى شود در بالادست آبشكن و از حدود فو اصلى كه قدرت جريان ثانويه و جرخش سلولها روند صعودى خود را آغاز نمودند (مطابق شكل ه) تنش برشى بسـتر نيز از متوسط تنش برشى در مسير مستقيم بالادست بيشتر شـده

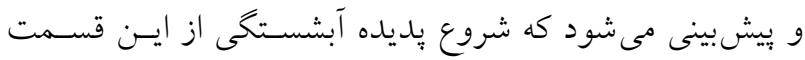
انجام شود. در اطراف بال آبششكن مقـدار تــش برشى بسـتر

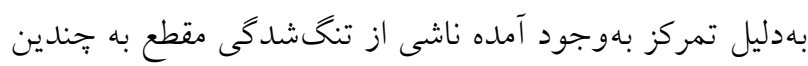
برابر متوسط تنش برشى در مسير مستقيم بالادست مسىرســ و بيشبينى مى شود كه حركت رسوبات از ايسن منطقـه و بـهـــور مشخص از دماغه بال آبشكن آغاز گردد. در منطقـه بـين بـال بالادست و ساحل خارجى مقادير تنش برشى در حسدود تـنش برشى متوسط در مسير مستقيم بالادست مسىباشـد كـه احتمـالاً رسوبات در اين منطقه بهواسطه گردابههاى قائم تشكيل شـده از بـان بستر جدا مىشوند و جريان در دماغه بال آبشكن و به سـمت 


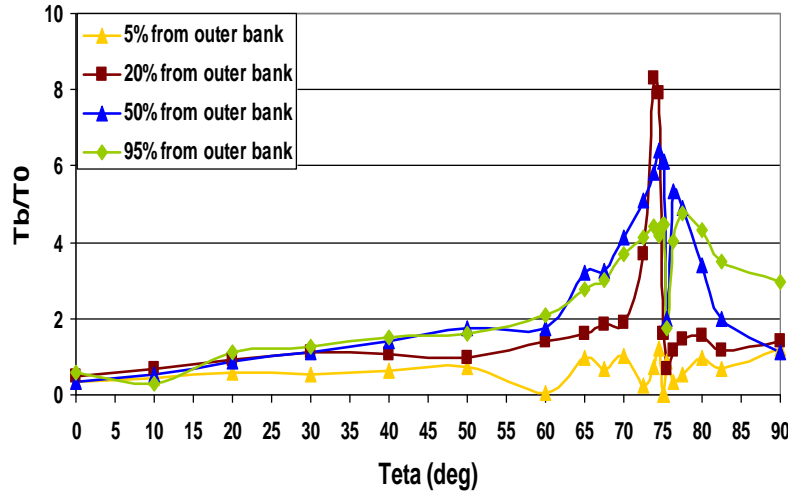

(ب)

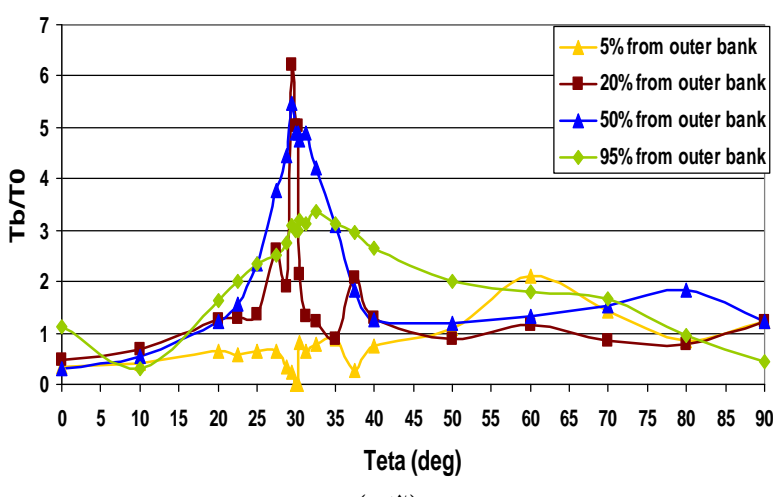

(الف)

شكل V. مقادير تنش برشى بىبعد شده بستر در فواصل مختلف از ساحل خارجى و براى آبشكنهاى مستقر

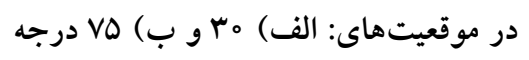

تنش برشى بستر در محدوده آبشكن بيشترين مقــدار را دارد و

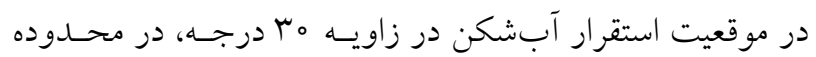
بين مها تا م V درجه نيز روند صعودى و نزولسى دارد ولسى ايسن

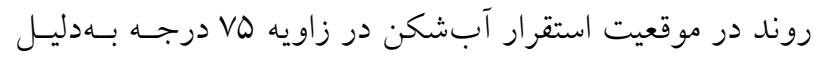

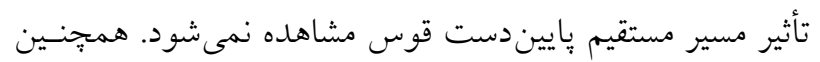

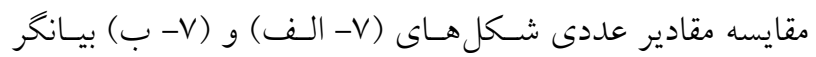

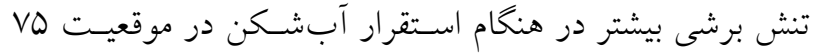

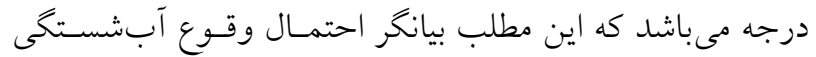

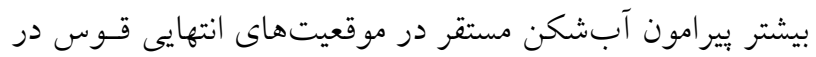
صورت متحرى بودن بستر مىباشد.

\section{نتيجه گيرى}

در اين مقاله بـه بررسـى آزمايشـاهى نحسوة تغييـرات قـدرت

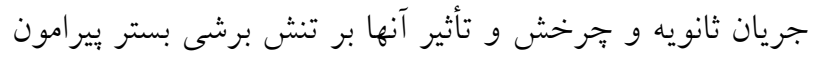

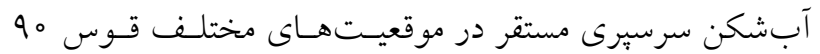

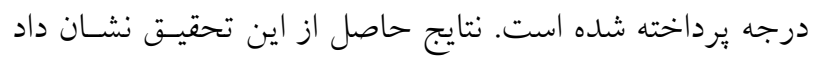

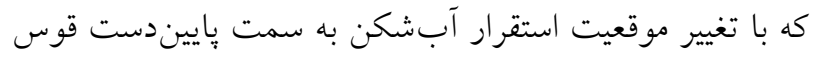

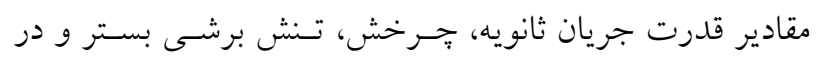

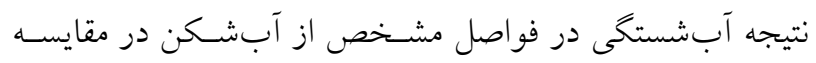

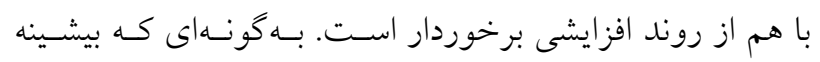

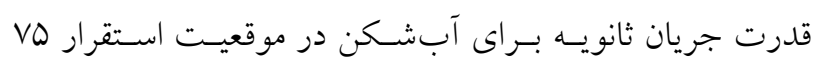

متوسط مسير مستقيم بالادست ( ) ) كمتر است و بين موقعيـت

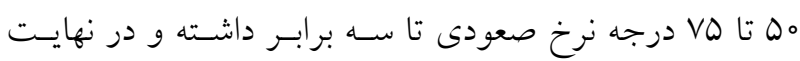
بهصورت نزولى مشاهده مى شود. بر اين اساس مى توان احتمال

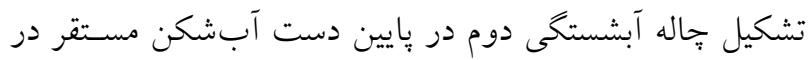

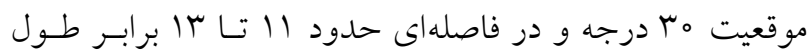
آبشكن نزديك به ساحل خارجى را انتظار داشـت. ايسن تغييـر

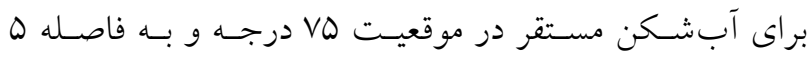
درصدى عرض كانال از ساحل خارجى (شكل V- ب) مشـاهده

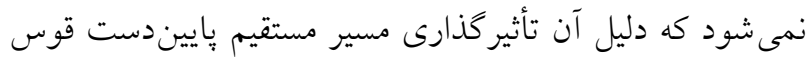

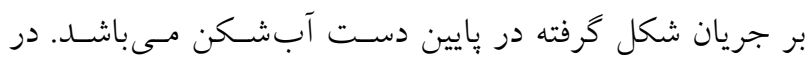

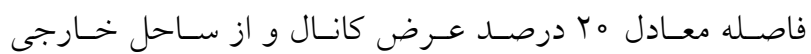
همانطور كه از شكل V مشاهده مسى شـود، تسنش برشسى بسـتر

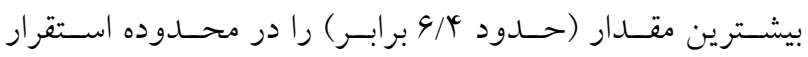

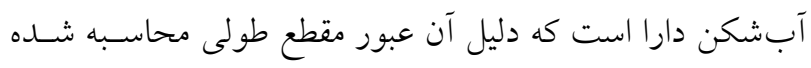

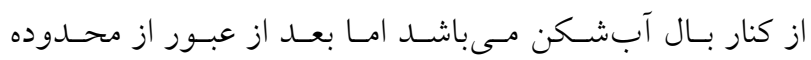

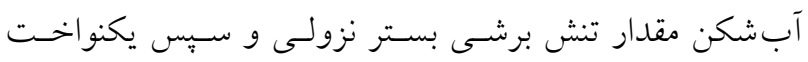

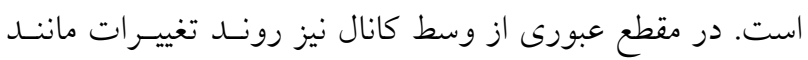

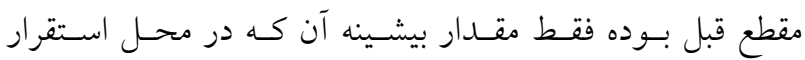
آبشكن است بهدليل دور شدن از بال آبشكن از مقدار بيشينه

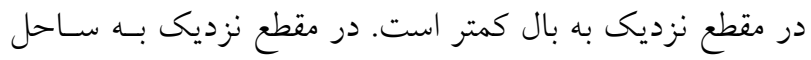

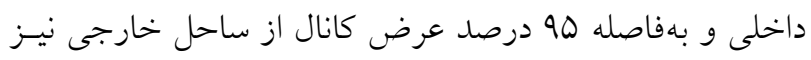




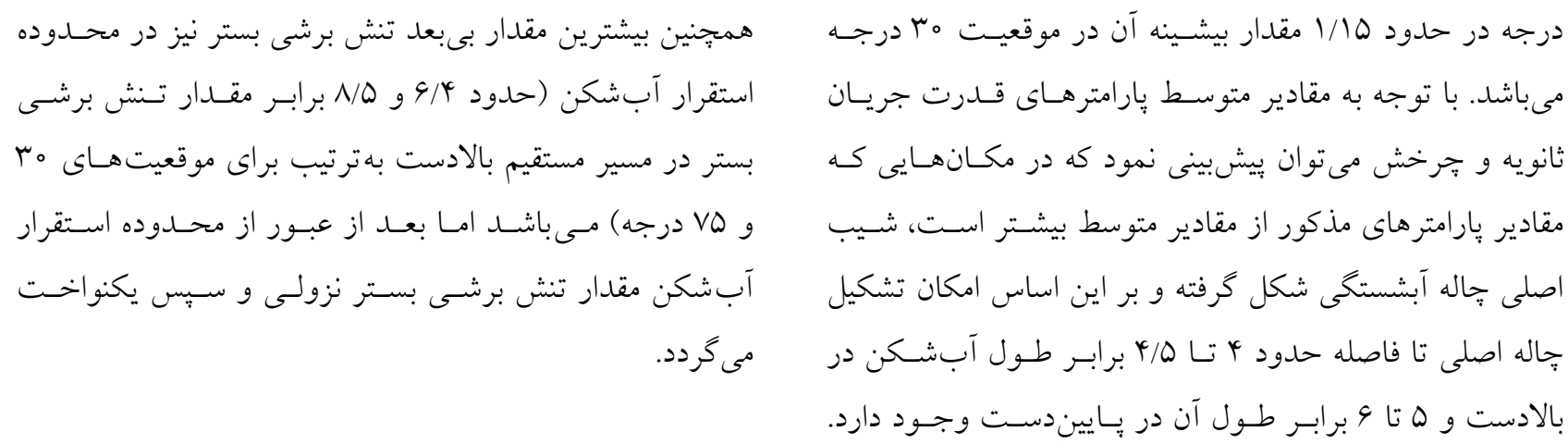

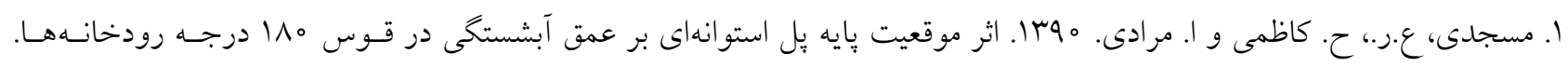

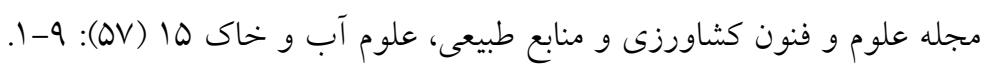

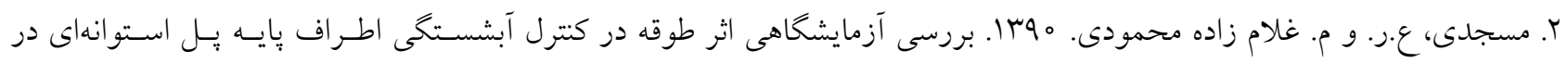

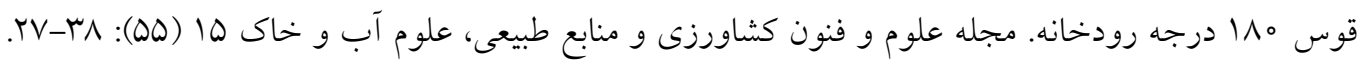

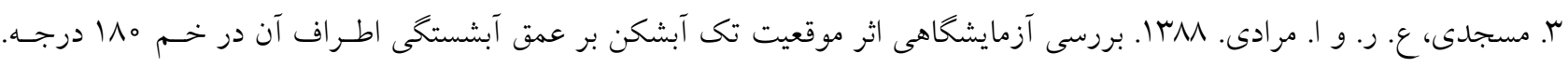

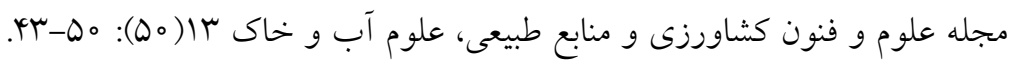

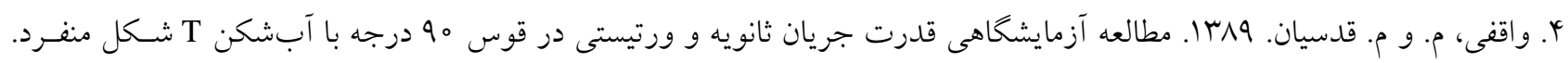

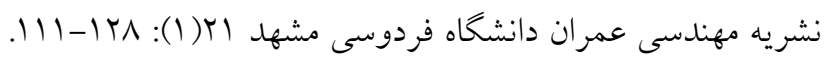

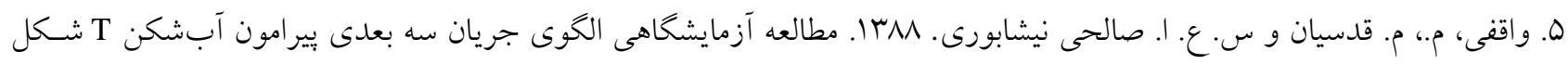

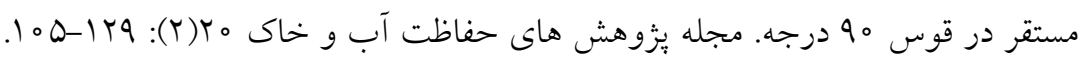

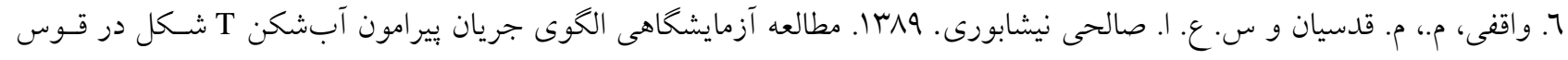

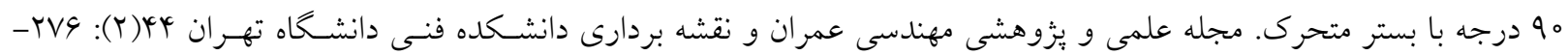

V. ياسى، م.، ن. طالب بيدختى، م. جوان و م. بينا. ویז|. راهنماى طراحى، ساخت و نخهارى آبشكنهاى رودخانهاى، نشـريه شـماره

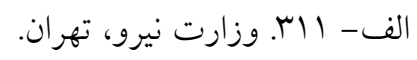

8. Ahmad, M. 1951. Spacing and protection of spurs for bank protection. Civil Eng. and Public. Rev. 46: 3-7.

9. Blanckaert, K. and W. H. Graf. 2001. Mean flow and turbulence in open-channel bend, J. of Hydraulic Eng. 127(10): 126-138.

10. Barbhuiya, A. K. and S. Dey. 2004. Turbulent flow measurement by the ADV in the vicinity of a rectangular crosssection cylinder placed at a channel side wall. Flow. Measur. and Instrum. 15 (4): 221-237.

11. Dey, S. and A. K. Barbhuiya. 2005. Turbulent flow field in a scour hole at a semi-circular abutment. Canadian. J. Civil. Eng. 32(1): 213-232.

12. Ghodsian, M. and M. Vaghefi. 2009. Experimental study on scour and flow field in a scour hole around a T-shaped spur dike in a $90^{\circ}$ bend. Int. J. Sediment. Res. 24(2): 145-158.

13. Lian, H. C., T. Y. Hsied and J. C. Yang. 1999. Bend-flow simulation using 2D depth-averaged mode. J. Hydraul. Eng. 125(10): 1097-1108.

14. Marion, A. and M. Zaramella. 2006. Effects of velocity gradients and secondary flow on the dispersion of solutes in a meandering channel. J. Hydraul. Eng. 132(12): 1295-1302.

15. Melville, B. W. 1992. Local scour at bridge abutment. J. Hydraul. Eng. 118(4): 615-631. 
16. Naji Abhari, M., M. Ghodsian, M. Vaghefi and N. Panahpur. 2010. Experimental and numerical simulation of flow in a $90^{\circ}$ bend. Flow. Measur. and Instrum. 21(3): 292-298.

17. Nouh M. A. and R. D. Townsend. 1979. Shear-stress distribution in stable channel bends. J. Hydraul. Div. 105(10): 1233-1245.

18. Shukry, A. 1950. Flow around bends in an open flume. Trans. American. Soc. Civil. Eng. 115(1): 751-779.

19. Tang, X. L., Z. C. Chen and F. Yang. 2006. Dynamic large eddy simulation of secondary flow near a groyne. Int. J. Nonlinear. Sci. and Num. Simul. 7(3): 257-262.

20. Ursic, M. C. 2011. Quantification of shear stress in a meandering native topographic channel using a physical hydraulic model. Master degree Thesis, Water Engineering, Faculty of Hydraulic Engineering, Colorado State University.

21. Vaghefi, M., A. Ahmadi and B. Faraji. 2015. The effect of support structure on flow patterns around T-shape spur dike in $90^{\circ}$ bend channel. Arab. J. Sci. and Eng. 40(5): 1299-1307.

22. Vaghefi, M., M. Akbari and A. R. Fiouz. 2015. An experimental study of mean and turbulent flow in a 180 degree sharp open channel bend: secondary flow and bed shear stress. KSCE J. Civil. Eng. 20 (4):1582-1593

23. Vaghefi, M., M. Ghodsian and A. Adib. 2012. Experimental study on the effect of Froude Number on temporal variation of scour around a T-shaped spur dike in a 90 degree bend. App. Mech. and Material 147: 75-79.

24. Vaghefi, M., M. Ghodsian and S. A. A. Salehi Neyshaboori. 2009. Experimental study on the effect of a T-shaped spur dike length on scour in a $90^{\circ}$ cannel bend. Arab. J. Sci. and Eng. 34(2B): 337-348.

25. Vaghefi, M., M. Ghodsian and S. A. A. Salehi Neyshaboori. 2012. Experimental study on scour around a T-Shaped spur dike in a channel bend. J. Hydraul. Eng. 138(5): 471-474.

26. Vaghefi, M., V. A. Mohsenimehr and M. Akbari. 2014. Numerical investigation of wing to web length ratios parameter of T-shaped spur dike in a 90 degree bend on scour pattern. J. River. Eng. 2(3): 45-52.

27. Vaghefi, M., Y. Safarpoor, S. S. Hashemi. 2015. Effects of relative curvature on the scour pattern in a $90^{\circ}$ bend with a T-shaped spur dike using a numerical method. Int. J. River. Basin. Manag. 13(4): 501-514.

28. Vaghefi, M., M. Shakerdargah and M. Akbari. 2014. Numerical investigation of the effect of Froude number on flow pattern around a submerged T-shaped spur dike in a $90^{\circ}$ bend. Turk. J. Eng. and Env. Sci. 38(2): 266-277.

29. Yang, S. Q. 2005. Interactions of boundary shear stress, secondary currents and velocity. Fluid. Dynamic. Res. 36: 121-136. 


\title{
The Effect of Secondary Flow Strength on Bed Shear Stress around T- Shaped Spur Dike Locating in Various Positions of a 90 Degree Bend with Rigid Bed
}

\author{
M. Vaghefi ${ }^{1^{*}}$, M. Ghodsian ${ }^{2}$ and M. Akbari ${ }^{1}$
}

(Received: Aug. 25-2015 ; Accepted: Dec. 6-2015)

\begin{abstract}
In this study, the effect of the secondary flow strength and vorticity on variations of bed shear stress for different positions of spur dike are compared through a mild $90^{\circ}$ bend along with a T-shaped spur dike in a rigid bed. To carry out these experiments, three dimensional velocimeters (ADV) have been used for measuring velocity. Moreover, a comparison has been made between velocity vectors and variations of streamlines along the bend; the secondary flow strength and vorticity values are estimated for various positions of spur dike, and their effects on bed shear stress variations have been analyzed. It is concluded that the maximum secondary flow strength is evident in a distance of 0.6 of spur dike's length at upstream under all these different positions of spur dike. Also the maximum vorticity position corresponds to the position of the maximum secondary flow strength, in front of spur dike's wing. According to these results, it is predicted that the maximum scour occurs near the position of maximum secondary flow strength and maximum vorticity. Besides, the path of sediments motion coincides with the maximum shear stress points locus.
\end{abstract}

Keywords: Secondary flow strength, Bed shear stress, T-shaped spur dike, 3-D velocimeter.

1. Dept. of Civil Eng., Technical and Eng. Faculty, Persian Gulf Univ., Bushehr, Iran.

2. Dept. of Water Eng., Civil Eng. Faculty, Tarbiat Modares Univ., Tehran, Iran.

*: Corresponding Author, Email: vaghefi@pgu.ac.ir 